\title{
A feiticeira: personagem histórica e ficcional das Américas de língua francesa
}

\author{
A feiticeira no imaginário \\ ficcional das Américas.
}

HANCIAU, Nubia.

Rio Grande: FURG/ABECAN, 2004. $374 \mathrm{p}$.

A publicação de $A$ feiticeira no imaginário ficcional das Américas é de importância capital para os estudos literários no Brasil, pois se trata de um alentado estudo que problematiza diferentes vieses da crítica literária contemporânea. Nubia Hanciau, professora titular da Fundação Universidade Federal do Rio Grande e doutora em Letras pela Universidade Federal do Rio Grande do Sul, discute temas fundamentais que irão atrair a atenção de todos aqueles que se interessam pela problemática da escritura feminina, mas também dos que se preocupam com as instigantes relações entre literatura e história e ainda dos que navegam nas águas dos imaginários coletivos das Américas.

O livro recebeu, em 2005, o Prêmio Pierre Savard de melhor ensaio na área de estudos canadenses, escrito em uma língua outra que o inglês e o francês, conferido pelo International Council for Canadian Studies/Conseil International d'Études Canadiennes (ICCS-CIEC), entidade com sede em Ottawa e que reúne 7000 canadianistas em 38 países do mundo.

A obra apresenta e discute sólida e atualizada bibliografia sobre as convergências entre discurso histórico e ficcional, tema palpitante na produção literária brasileira contemporânea, e mergulha fundo nas origens e deslocamentos do mito da feiticeira desde suas origens na Europa medieval até sua transformação em símbolo de libertação da mulher no contexto literário das três Américas. Fazer emergir a figura da feiticeira como persongem recorrente em autoras de língua francesa das Américas é a estratégia da autora que, ao desconstruir os estereótipos negativos associados à figura mítica da feiticeira, apresenta uma nova interpretação dessa personagem associada agora à resistência, reabilitando sua imagem na posição de sujeito da história e de heroína ficcional.

Nubia Hanciau nos dá uma soberba lição de literatura comparada, tomando a figura da feiticeira como fio condutor das relações culturais e literárias interamericanas, consolidando essa inovadora linha de pesquisa na qual se inscreve seu trabalho. Esse ambicioso projeto foi realizado com grande competência, devendo contribuir para colmatar lacunas nos estudos literários brasileiros onde autoras que escrevem em língua francesa no contexto americano, como Nancy Huston (Canadá), Anne Hébert (Québec) e Maryse Condé (Antilhas Francesas), só agora começam a ser conhecidas. Algumas das obras dessas autoras já estão traduzidas no Brasil e outras certamente o serão em breve, sobretudo após a publicação do trabalho de Nubia Hanciau, que sem dúvida contribuirá de maneira substantiva para a divulgação das literaturas francófonas em nosso país e para a consolidação do comparativismo literário interamericano.

Vale citar trecho do prefácio, escrito por Maria Bernadette Porto, professora da Universidade Federal Fluminense, e sem sombra de dúvidas uma das maiores especialistas, no Brasil, na área das literaturas francófonas:

Cabe salientar um dos pontos mais rentáveis da análise de Nubia Hanciau: a sugestão de que, nos romances escolhidos, a feitiçaria se manifesta não só no nível dos personagens, mas também no plano da escrita, o que se verifica principalmente em Instrument des ténèbres (1996), de Nancy Huston. Aqui podem ser evocados os vínculos entre escrita e culinária. Ao reler La sorcière, de Jules Michelet, o crítico Jean-Pierre Richard afirmou: "Os alimentos se escrevem, como as palavras se comem" (1979, p. 192), o que corrobora o parentesco entre duas artes de fazer le de dizer, no caso da escrita), cujo trabalho de elaboração exige preparo, misturas, transformações, relacionando-se ainda ao gosto (p. 12).

Antes de passar à análise minuciosa e inspirada das obras mais relevantes dessas três escritoras francófonas das Américas nas quais a 
feiticeira emerge como figura literária, Nubia Hanciau apresenta uma frutífera reflexão sobre História e Nova História e também sobre a feiticeira como personagem histórica. É de grande interesse a síntese apresentada sobre as migrações da figura da feiticeira do imaginário europeu para o imaginário americano. Só então as obras Les enfants du sabbat (1975), da quebequense Anne Hébert, Moi, Tituba sorcière.. noire de Salem (1986), da antilhana Maryse Condé, e Instruments des ténèbres (1996), da canadense Nancy Huston, são estudadas do ponto de vista da utilização simbólica da fascinante figura da feiticeira. A autora comprova com maestria que, "mais do que protagonistas vítimas, rebeldes, histéricas, possuídas ou loucas, as autoras Hébert, Condé e Huston fazem surgir no romance heroínas que promovem a feiticeira, transformada e travestida de novos valores, dinâmica, ativa e criativa" (p. 259).

Anne Hébert (1916-2000) já havia merecido aprofundado estudo por parte de Nubia Hanciau que, em sua dissertação de mestrado, estudou a fundo várias obras romanescas e poéticas da mais renomada de todas as escritoras do Quebec, em todos os tempos, e alvo do maior número de estudos em escala internacional, sobretudo na França, país onde publicou a maioria de seus livros. Tendo vivido em Paris por longos anos, a autora não esconde sua profunda vinculação com o "pays natal", o Quebec, que é o espaço preferencial por onde circulam seus personagens. Preocupa-se ao mesmo tempo com a construção de uma identidade cultura quebequense e com a condição feminina em uma nação onde a forte presença da Igreja Católica, nos primeiros tempos da colonização, deixou marcas profundas no imaginário feminino que viveu essa influência como castração da sexualidade e da feminilidade.
Maryse Condé (1937-...) reconstrói através de seus numerosos romances, alguns já traduzidos para o português, a imagem de sua situação histórica enquanto mulher negra, antilhana, originária de um departamento de além mar da França, a Guadeloupe, bem como os conflitos que enfrenta sua escritura que se engendra em um contexto híbrido como o caribenho, onde múltiplos universos culturais se interpenetram como o africano, o europeu, o indiano, etc.

Nancy Huston (1953-...), nascida na província de Alberta, no Canadá, tem uma trajetória surpreendente, pois inicia escrevendo em inglês (Songs of the Praries, que ganha em seguida versão para o francês como Cantiques des plaines, talvez seu livro mais conhecido, editado em 1993), passando em seguida a adotar a língua francesa como língua de escritura. Hoje grande parte de seus livros apresenta versões em língua inglesa e francesa elaboradas pela própria autora, radicada há mais de 20 anos em Paris.

Trabalhar com a diversidade temática e narrativa dessas três fascinantes autoras não é tarefa para principiantes. Nubia Hanciau sai-se muito bem dessa corajosa empreitada, apresentando o perfil de protagonistas feiticeiras que foram perseguidas pela Inquisição como subversivas, histéricas, possuídas ou loucas, mas que revelam, nos romances das escritoras estudadas, uma dimensão outra, de verdadeiras heroínas que praticam a feitiçaria não como forma de danação mas como forma de salvação. Trata-se de personagens ao mesmo tempo insólitas e apaixonantes que desafiam, do início ao fim de suas trajetórias, a imaginação dos leitores, fazendo-os reexaminar seus pontos de vista e seus preconceitos. O livro $A$ feiticeira no imaginário ficcional das Américas é um convite à leitura dessas obras.

Zilá Bernd

Universidade Federal do Rio Grande do Su 